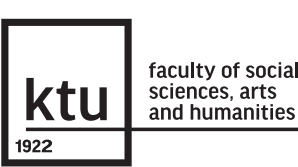

SAL 38/2021

Research Journal Studies about Languages pp. $115-130$ ISSN 1648-2824 (print) ISSN 2029-7203 (online) DOI 10.5755/j01.sal.1.38.27437
LINGUISTICS / KALBOTYRA

A Two-Man Show: Stylometric Analysis of Personal Names in Rudolf Slánský’s Staged Trial Newspaper Reports

Received 08/2020

Accepted 05/2021

crossef $h t t p: / / d x . d o i . o r g / 10.5755 /$ j01.sal.1.38.27437

HOW TO CITE: David, J., Davidová Glogarová, J., \& Místecký, M. (2021). A Two-

Man Show: Stylometric Analysis of Personal Names in Rudolf Slánský's Staged Trial Newspaper Reports. Studies about Languages / Kalbų studijos 38, 115-130. http://doi. org/10.5755/j01.sal.1.38.27437

\title{
A Two-Man Show: Stylometric Analysis of Personal Names in Rudolf Slánský's Staged Trial Newspaper Reports
}

\section{Dviejų vyrų šou: stilometrinė asmenvardžių analizė laikraščio straipsniuose nušvietusiuose Rudolfo Slanskio parodomojo teismo procesą}

\author{
JAROSLAV DAVID, University of Ostrava, Czech Republic \\ JANA DAVIDOVÁ GLOGAROVÁ, University of Ostrava, Czech Republic \\ MICHAL MÍSTECKÝ, University of Ostrava, Czech Republic
}

\begin{abstract} ský's staged trial, which was held against the leaders of the Communist Party of Czechoslovakia - mostly of the Jewish origin - who were "uncovered" as political enemies; the trial took place in an anti-Semitic atmosphere. The examined texts were published in the period of November 21-28, 1952, in Rudé právo, the main newspaper of the Communist Party of Czechoslovakia. Proper names, mostly personal names, are analysed from several perspectives. The quantitative analysis is focused on the keywords of the studied texts and typical collocations of the names. The qualitative analysis, developing the quantitatively researched data, is aimed at the image of enemy or traitor and its presentation via thematization of personal names. The ways of language presentation of the Jewish origin of the accused are in the scope of the contribution as well. Within the scope of collocation analysis, the newspaper texts on the trial were contrasted with the ones published by Rudé právo on the occasion of Rudolf Slánský's $50^{\text {th }}$ birthday (July 31, 1951).
\end{abstract}

The paper is aimed at personal names (anthroponyms) in newspaper reports on Rudolf Slán-

KEYWORDS: Rudolf Slánský's staged trial, personal names, keyword analysis, collocation analysis, thematization of personal names, opinion journalism, Rudé právo newspaper.

\section{Introduction}

The goal of the paper is to carry out a collocation analysis of the proper names in the texts that were published in November 1952 in Rudé právo, the main newspaper of the Communist Party of Czechoslovakia, during the staged trial of Rudolf Slánský, a prominent Communist politician. This analysis will be complemented by keyword investigations in the texts. These approaches may provide a novel overview of the complex background of that-time breakthrough events.

Slánský's trial was one of many that were arranged in most Soviet bloc countries at the beginning of the 1950s. Recently, the presentation of the trial in Rudé právo, mostly from the perspective of persuasive strategies, was paid attention in the qualitative and descriptive analysis carried out by Jindřiška Svobodová (2016). In her text, 
personal names of the key participants are not examined, although several times they are mentioned as means of labelling the accused persons with pejorative expressions (e.g., p. 129).

The analysis of this paper is intensely concentrated on personal names, taking the quantitative approach as its basis (cf. Místecký, 2019; Davidová Glogarová \& Kubát, 2020; see also Davidová Glogarová \& David, 2020). The basic functions of proper names are object-referential ones; the proper names are regarded as the referring expressions which have no sense, i.e., their overall meaning is not divisible into parts. This fact does not mean that the proper names do not have any meaning - they have denotations, connotations, they are used in metaphorical way, etc. (Šrámek, 1999; Coates, 2006; Nyström, 2016). Formally, the ways of their usage can be examined through the collocation analysis, i.e., their co-occurrences with other words in the text. For instance, if the basic function of a personal name is to refer to a person, it appears mostly in (usual) collocations with the expressions such as Mrs, $\mathrm{Mr}$, doctor, etc., or in pairs consisting of first name and surname. (Re-)semantization (and thematization, i.e., the process during which they become the topics of the text) of proper names can thus be understood as a change of their basic object-referential function; in accordance with this change, the names may acquire different collocation surroundings. In the analysed texts, we presuppose use of expressive lexis and rhetoric devices, emphasis put on Zionism and the Jewish origin of the accused, and a polar presentation of the Slánský-Gottwald pair.

On July 31, 1951, the issue of Rudé právo delivered the first and two other pages to the $50^{\text {th }}$ birthday of Rudolf Slánský. At that time, he was the second man in the Communist Party of Czechoslovakia hierarchy. Whereas Klement Gottwald, the president of the Czechoslovak Republic and Slánskýs close friend, was the head of the party, Rudolf Slánský held the position of the general secretary of the Central Committee. At this festive occasion, Slánský was also awarded for his extraordinary effort to build Socialism with the Order of Socialism, and his selected articles and speeches were published in two volumes.

Sixteen months later, on November 28, 1952, Ivan Skála, a young and enthusiastic Communist poet, wrote Tři lavice [Three Benches], a text presenting an exalted reflection of the trial of Rudolf Slánský. The article, published in Rudé právo, summed up the result of the trial labelled in that-time Communist jargon "Trial of the Leadership of the Anti-State Conspirational Centre Headed by Rudolf Slánský": "However, all this terrible weight, the sabotage have piled up for years, the betrayal of vampires, huge tangles of leeches, all this terrible weight fell down out of our people. It was hard to breathe under the weight, but mercenary soldiers of imperialism have failed to smother us. Now without them [Slánský and his colleagues], we will work and sing with a calm mind, we will rock babies on knees. Now, they will be suffocated under the weight themselves. All service should be paid for accordingly. To a dog, a dog's death!" (Skála, 1952).

Eleven persons, out of fourteen people accused in the trial, were sentenced to death in hanging, three people to life imprisonment. Except Rudolf Slánský, there were Vlado (Vladimír) Clementis, minister of foreign affairs, other high state officers, and also André Simone, a respected journalist from Rudé právo, among the victims of the trial (for detailed information on the background of the trial and the accused persons, see Pelikán, 1975; Lukes, 2008; cf. Ströbinger, 1991; Kaplan, 1992; Pernes \& Foitzik, 2005).

The main hearing was held from November 20 to November 27, 1952. The aim of the trial was to uncover so-called "internal enemies" in the Communist party, so that the causes of mostly economic problems could be connected with selected scapegoats (as to the concept of enemy during the Communist era, see Palivodová, 2012; Nečasová, 2020). The trial was accompanied with a very intensive anti-Semitic campaign ${ }^{2}$ as well - although it was not openly

\footnotetext{
${ }^{1}$ The sources, which are written in Czech, were translated into English by the authors of the paper.

${ }^{2}$ In his memory book Doznání [The Confession], Artur London, a diplomat sentenced in Slánskýs trial for life imprisonment and released from prison in 1956, mentioned this aspect of the trial many times: "When a new name appears, officers want to know if he is a Jew. Those who are skilful ask in this way: 'What was his name before? Did he change his name in 1945?' [...] The goal is to accumulate the highest number of Jews possible in the record. When I mention two or three names, the only name that is recorded is the one that sounds like a Jewish one. This repeating system, however primitive it may seem, has finally produced the expected image - that an accused person had contacts with Jews only, or with a considerable number of Jews at least. [...] Nevertheless, Jews are not spoken about" (London, 1969, p. 197). An increase of anti-Semitism is also reflected in book Na vlastni kǔži [Having First-hand Experience] by Heda Margoliová-Kovályová (2003, pp. 161, 174), wife of Rudolf Margolius, who was sentenced to death (cf. also Šimová, 2014). The fact that anti-Semitism was permanently present in the Communist party policy is also illustrated with the document known as Poučeni z krizového vývoje ve straně a společnosti [The Lesson Drawn from the Crisis in the Party and Society]. The text determined the Communist party policy for the next twenty years, after the Soviet occupation of Czechoslovakia in 1968 until the Velvet Revolution in 1989. Zionism is mentioned here among the anti-Socialist forces; within its prominent representatives, the name of Eugen Löbl is listed (Poučení, 1988, p. 19). He was an economic expert sentenced in Slánský's trial for life imprisonment and released from prison in 1960.
} 
declared -, which was influenced by the that-time clash between the Soviet Union and the State of Israel (Šimová, 2014; cf. Palivodová, 2012). At the turn of the 1950s, the same stage trials, arranged according to the Soviet model, were held in other people's democratic countries in Central and Southern Europe - in Hungary (the trial of László Rajk), and Bulgaria (Traicho Kostov Djunev); in Germany (Paul Merker, Franz Dahlem) and Poland (Władysław Gomułka), the trials were prepared, but because of Stalin's death in March 1953 they were not launched.

The importance of the trial from the perspective of the Czechoslovak Communist regime is illustrated by the accent put on its public presentation. Every day, Czechoslovak people received information on the trial - it was presented through radio broadcasting, cinema newsreels, and through the coverages and other texts published in newspapers, too. The so-called "betrayers" were also condemned by a number of resolutions requiring death for them; many representatives of Czech culture expressed their stances, e.g., writers and poets Ivan Skála, Jan Pilař, Ivan Olbracht, Jarmila Glazarová, Karel Konrád, Josef Kainar, and also historian and minister of education Zdeněk Nejedlý (Brabec, 1969; Kourová, 2013; cf. Nejedlý, 1953). At the beginning of 1953, the full-text version of the trial acta $^{3}$ was published as a book in Czech (Proces, 1953a), Slovak (Proces, 1953b), German (Prozess, 1953), English (Trial, 1953), Spanish (Proceso, 1953), Russian (Process, 1953), French (Procès, 1953), and Hungarian (Bünpere, 1953); at the same time, a booklet analysing the trial was released, too (Bacílek, 1953).

\section{Material and Methodology}

In the paper, we aim at the texts that were published in Rudé právo, the main newspaper of the Communist Party of Czechoslovakia, during the days of the trial. The newspaper articles are now open source (see "Rudé právo" in the Corpus section of References). The first, main set of analysed texts was published between November 21 and November 28, 1952 , as the facts about the trial day were always presented in the next-day issue of the newspaper. The corpus consists of everyday coverages of the trial, texts, and letters (written by ordinary people, mostly workers, and also by other supporters) condemning Rudolf Slánský and the accused and calling for capital punishment for them. The titles of the articles were considered part of the text, as well as the names of the authors, if indicated; the latter approach was adopted as the names are accompanied by the characteristics of the people (e.g., "J. Čudek, secretary of the factory committee of the Communist Party of Czechoslovakia" - RP November 26, 1952, p. 1). The corpus, which will be henceforth referred to as "trial corpus", consists of 48 articles; from the quantitative perspective, there are 26,306 tokens, 8,344 word-form types, and 9,668 lemmata. The corpus is available as Slánský_corpus_1_1952 (see the Corpus section of References).

The second, complementary corpus comprises texts published in Rudé právo on 31 July 1951 and pertaining to Slánský's $50^{\text {th }}$ birthday (henceforth referred to as "birthday corpus"). These include mostly festive and appreciative letters and essays concerning life and works of the protagonist. The corpus consists of 9 texts, 9,436 tokens, 3,689 word-form types, and 4,175 lemmata. The texts were made ready in the same way as the ones in the first corpus. The set of articles is available as Slánský_corpus_2_1951 (see the Corpus section of References).

The first-corpus texts were analysed via two quantitative methods - first, we calculated the keywords of the articles (cf. Davidová Glogarová \& Kubát, 2020), taking - as the reference ones - the corpora of TOTALITA1952, TOTALITA1952-1969, and TOTALITA (their sizes are given in Table 1). The reference corpus is the background sample of language, to which the frequencies of words in the studied corpus are compared. The reference corpora of our choice encompass Rudé právo articles, propaganda books and booklets, and other printed propaganda material published in the given years (the third corpus contains texts from 1952, 1969, and 1977; Cvrček et al., 2010; cf. Schmiedtová, 2014).

Table 1 Sizes of the reference corpora

\begin{tabular}{c|c} 
Corpus & Size [tokens] \\
\hline TOTALITA1952 & $4,903,239$ \\
\hline TOTALITA1952-1969 & $9,526,347$ \\
\hline TOTALITA & $15,350,738$ \\
\hline
\end{tabular}

\footnotetext{
${ }^{3}$ Eugen Löbl in his Svedectvo o procese [Testimony of the Trial] noted that not all speeches were captured in the printed version of the trial (Löbl, 1968, p. 61).
} 
The level of significance was set up to 0.0001; whether the difference between the frequencies of the word is statistically significant was determined on the grounds of log-likelihood test. The minimal researched frequency of the word occurrence was 5 . The results of the analysis were wordforms, i.e., words in various morphological forms (not lemmata). The relevance of the difference in the occurrences of the word in the two corpora is expressed by DIN (Difference Index), which is mathematicised as follows:

$$
D I N=100 \times \frac{f_{r}(\text { targ })-f_{r}(r e f)}{f_{r}(\text { targ })+f_{r}(r e f)},
$$

where $f_{r}$ (targ) stands for the relative frequency of the word in the trial corpus (= target corpus) and $f_{r}$ (ref) for the same in the respective reference corpus. In the analysis, only words with $D I N>0.97$ were taken into account, pronouns, prepositions, conjunctions, and numbers being excluded. The results were obtained using the KWords software, which is part of the Czech National Corpus analytical tools. ${ }^{4}$

Both corpora were involved in the analysis focusing on collocations of lemmatized proper names "Slánský" and "Gottwald". The research was carried out in the LancsBox software (Brezina et al., 2015), which was also used for lemmatizing "Gottwald"; as to "Slánský", we lemmatized it manually. The span of the collocate occurrence was given as $-5 /+5$. The collocations (with the minimal occurrence of 5 ) are determined on the basis of the Mutual Information score, the formula of which reads as follows:

$$
M I=\log _{2} \frac{N \times f(x y)}{f(x) \times f(y)},
$$

where $N$ stands for the corpus size (in words), $f(x)$ for the frequency of the studied lemma ("Slánský" or "Gottwald"), $f(y)$ for the frequency of a collocate, and $f(x y)$ for the number of cases of their co-occurrence (Cvrček, 2019). We opted for this measure, as it finds "exclusive" collocations and takes into account low-frequency words (McEnery et al., 2006, pp. 57). We analyse the MI scores of 5 and higher values, as it has been empirically found out that the lower ones tend to capture collocations with functional words only.

Keywords

Analysis and Interpretation
The results of the analysis are presented in Tables 2, 3, and 4. Grammatical abbreviations are used to specify the contexts in which the words were used (except the situations in which the English form literally renders the Czech one - e.g., noun and adjective nominatives). The semi-colon indicates that the wordform is ambiguous as to its morphological structure (e.g., "gen; acc"). The list of the abbreviations is given in the appendix to the study.

\begin{tabular}{|c|c|c|c|c|c|}
\hline & Keyword & Translation & DIN & Fq (targ) & $\mathrm{Fq}(\mathrm{ref})$ \\
\hline 1 & trockisticko & Trockyist [in compounds] & 100 & 16 & 0 \\
\hline 2 & americko & American [in compounds] & 99 & 7 & 1 \\
\hline 3 & zrůda & monster & 98 & 5 & 5 \\
\hline 4 & poslouchej & listen [imp, sg] & 98 & 5 & 6 \\
\hline 5 & zrůdy & monster [gen, sg; nom, pl; acc, pl] & 98 & 9 & 11 \\
\hline 6 & vlado & Vlado & 97 & 5 & 8 \\
\hline
\end{tabular}

Table 2 Keywords in the trial corpus - the TOTALITA1952 reference corpus

${ }^{4}$ See the References section of the paper. 


\begin{tabular}{c|c|c|c|c|c}
\hline 7 & lavice & bench & 97 & 10 & 22 \\
\hline 8 & nenáviděli & hated [3rd person, pl] & 97 & 5 & 11 \\
\hline 9 & lotrů & scoundrels [gen] & 97 & 6 & 14 \\
\hline 10 & sionismus & Zionism & 97 & 6 & 14 \\
\hline 11 & smečku & gang [acc] & 97 & 6 & 14 \\
\hline
\end{tabular}

Table 3 Keywords in the trial corpus - the TOTALITA1952-1969 reference corpus

\begin{tabular}{|c|c|c|c|c|c|}
\hline & Keyword & Translation & DIN & $\mathrm{Fq}$ (targ) & $\mathrm{Fq}(\mathrm{ref})$ \\
\hline 1 & trockisticko & Trockyist [in compounds] & 100 & 16 & 0 \\
\hline 2 & americko & American [in compounds] & 99 & 7 & 2 \\
\hline 3 & zrůda & monster [gen, sg; nom, pl; acc, pl & 99 & 5 & 6 \\
\hline 4 & zrůdy & monster [acc] & 99 & 9 & 11 \\
\hline 5 & poslouchej & listen [imp, sg] & 99 & 5 & 7 \\
\hline 6 & smečku & gang [acc] & 98 & 6 & 14 \\
\hline 7 & kosmopolita & cosmopolitan [noun] & 98 & 8 & 19 \\
\hline 8 & švermu & Šverma [acc] & 98 & 5 & 12 \\
\hline 9 & odporná & disgusting [fem] & 98 & 7 & 17 \\
\hline 10 & lotrů & scoundrels [gen] & 98 & 6 & 15 \\
\hline 11 & sionismus & Zionism & 98 & 6 & 15 \\
\hline 12 & antisemitismus & anti-Semitism & 98 & 5 & 15 \\
\hline 13 & nenáviděli & hated [3rd person, pl] & 98 & 5 & 15 \\
\hline 14 & lavice & bench & 97 & 10 & 32 \\
\hline 15 & výslechem & interrogation [instr] & 97 & 8 & 26 \\
\hline 16 & zaprodanci & betrayers & 97 & 6 & 20 \\
\hline 17 & kosmopolity & cosmopolitan [noun, gen] & 97 & 5 & 17 \\
\hline 18 & přelíčení & session & 97 & 20 & 71 \\
\hline 19 & sionisté & Zionists & 97 & 8 & 29 \\
\hline 20 & napáchali & committed [3rd person, pl] & 97 & 12 & 45 \\
\hline 21 & reicina & Reicin [gen; acc] & 97 & 15 & 59 \\
\hline 22 & sebranka & rabble & 97 & 5 & 20 \\
\hline 23 & spiklence & conspirators [acc] & 97 & 5 & 20 \\
\hline 24 & stihne & will afflict [3rd person, sg] & 97 & 5 & 20 \\
\hline 25 & špionáži & espionage [loc] & 97 & 6 & 25 \\
\hline 26 & sionismu & Zionism [gen; loc] & 97 & 7 & 30 \\
\hline 27 & reicin & Reicin & 97 & 29 & 126 \\
\hline 28 & tíhou & weight [instr] & 97 & 6 & 27 \\
\hline
\end{tabular}


Table 4 Keywords in the trial corpus - the TOTALITA reference corpus

\begin{tabular}{|c|c|c|c|c|c|}
\hline & Keyword & Translation & DIN & $\mathrm{Fq}$ (targ) & Fq (ref) \\
\hline 1 & trockisticko & Trockyist [in compounds] & 100 & 16 & 0 \\
\hline 2 & americko & American [in compounds] & 99 & 7 & 2 \\
\hline 3 & zrůda & monster [gen, sg; nom, pl; acc, pl] & 99 & 5 & 6 \\
\hline 4 & zrůdy & monster [acc] & 99 & 9 & 11 \\
\hline 5 & poslouchej & listen [imp, sg] & 99 & 5 & 9 \\
\hline 6 & smečku & gang [acc] & 99 & 6 & 14 \\
\hline 7 & kosmopolita & cosmopolitan [noun] & 99 & 8 & 19 \\
\hline 8 & švermu & Šverma [acc] & 99 & 5 & 12 \\
\hline 9 & lotrů & scoundrels [gen] & 98 & 6 & 15 \\
\hline 10 & odporná & disgusting [fem] & 98 & 7 & 19 \\
\hline 11 & kosmopolity & cosmopolitan [noun, gen] & 98 & 5 & 17 \\
\hline 12 & výslechem & interrogation [instr] & 98 & 8 & 29 \\
\hline 13 & lavice & bench & 98 & 10 & 38 \\
\hline 14 & nenáviděli & hated [3rd person, pl] & 98 & 5 & 19 \\
\hline 15 & reicina & Reicin [gen] & 98 & 15 & 59 \\
\hline 16 & napáchali & committed [3rd person, pl] & 98 & 12 & 50 \\
\hline 17 & sebranka & rabble & 98 & 5 & 21 \\
\hline 18 & spiklence & conspirators [acc] & 98 & 5 & 21 \\
\hline 19 & reicin & Reicin & 98 & 29 & 126 \\
\hline 20 & stihne & will afflict [3rd person, sg] & 98 & 5 & 22 \\
\hline 21 & přelíčení & session & 98 & 20 & 90 \\
\hline 22 & zaprodanci & betrayers & 98 & 6 & 28 \\
\hline 23 & špionáži & espionage [loc] & 97 & 6 & 31 \\
\hline 24 & vlado & Vlado & 97 & 5 & 26 \\
\hline 25 & zločinec & criminal & 97 & 13 & 71 \\
\hline 26 & pankráci & Pankrác [loc] & 97 & 6 & 33 \\
\hline 27 & kosmopolitní & cosmopolitan [adj] & 97 & 7 & 39 \\
\hline 28 & tíhou & weight [instr] & 97 & 6 & 34 \\
\hline 29 & nacionalista & nationalist & 97 & 5 & 29 \\
\hline 30 & frejky & Frejka [gen] & 97 & 7 & 41 \\
\hline 31 & podlé & $\begin{array}{c}\text { base [adj - neu, nom; neu, acc; fem, gen; fem, dat; fem, } \\
\text { nom, pl; fem, acc, pl] }\end{array}$ & 97 & 8 & 48 \\
\hline 32 & titem & Tito [instr] & 97 & 6 & 36 \\
\hline 33 & geminder & Geminder & 97 & 15 & 94 \\
\hline
\end{tabular}




\begin{tabular}{|c|c|c|c|c|c|}
\hline 34 & špionem & spy [instr] & 97 & 7 & 44 \\
\hline 35 & lavici & bench [acc; loc] & 97 & 13 & 83 \\
\hline 36 & banda & gang & 97 & 42 & 271 \\
\hline 37 & svědci & witnesses & 97 & 5 & 33 \\
\hline 38 & obžalovaných & accused [past part - masc, gen, pl] & 97 & 18 & 119 \\
\hline 39 & sabotoval & sabotaged [3rd person, sg] & 97 & 5 & 34 \\
\hline 40 & evžena & Evžen [gen; acc] & 97 & 6 & 41 \\
\hline 41 & sionistů & Zionists [gen] & 97 & 10 & 69 \\
\hline 42 & napáchané & $\begin{array}{l}\text { committed [past part - neu, nom; neu, acc; fem, gen; } \\
\text { fem, dat; fem, nom, pl; fem, acc, pl] }\end{array}$ & 97 & 5 & 35 \\
\hline 43 & špion & spy & 97 & 11 & 78 \\
\hline 44 & antisemitismus & anti-Semitism & 97 & 5 & 36 \\
\hline 45 & společníků & companions [gen] & 97 & 7 & 51 \\
\hline
\end{tabular}

There are several points to be commented upon. First, with the reference corpus changing, there is a rising number of keywords, which may indicate that the vocabulary used in the 1950s Rudé právo was not employed so much in later decades. It needs to be noted that many of the expressions are openly expressive and inimical ("monster", "gang", "scoundrels", "disgusting", "base"), and they are closely linked to the anti-espionage and enemy-denoting lexis used at the beginning of the Communist era in Czechoslovakia ("espionage", "spy", "conspirators", "cosmopolitan", "nationalist"). The same logic seems to apply for names - whereas in the TOTALITA1952-referenced research, keyword names are not mentioned, the way the alleged perpetrators were being forgotten over time is symbolized by their soaring prominence in the other two investigations (see, for instance, "Reicin", "Frejka", "Evžen" [two people of the same name - Löbl and Klinger], even "Tito"). The only exception in Table $\mathbf{2}$ is "Vlado", the first name of the Communist minister of foreign affairs Vlado (Vladimír) Clementis; this may be due to the fact that it is an unusual name form in the context of Czech anthroponymy, but there may also have been a connection with the special circumstances of Clementis's accusation - he was arrested in January 1951 on the grounds of "bourgeois nationalism" and added, as a very prominent person, to Slánský's trial later.

It is of importance that in Tables 3 and $\mathbf{4}$, besides the names of the protagonists of the trial, their alleged victim became salient, too - Jan Šverma, martyr of the anti-Nazi resistance movement. This supported the claim that Slánský and his companions may have been responsible, at least metaphorically, for the death of cardinal members of the WWII Communist underground (including, as another example, Julius Fučík, a Czech journalist put to death by the Nazis). Compare the following examples.

"[...] criminal Slánský brought about the death of national hero Jan Šverma [...]" (RP November 21, 1952, p. 1).

"At the court, the whole gallery of rogues paraded, headed by Slánský - Trockyists, Zionists, bourgeois nationalists, and, under these covers, war criminals, Gestapo agents, multiple spies of capitalist countries, murderers of Jan Šverma and Julius Fučik and the best sons of our Communist party" (RP November 28, 1952, p. 1).

Moreover, their accusation of the crimes was frequently linked to their gangster aim to kill the president Klement Gottwald as well (see Part 4). In general, the general oblivion of the accused in the newspaper may have been an intentional strategy used by the Communist party, but it is more probable that the topic was closed and did not need any reopening in the press.

As presupposed, the atmosphere of the trial must have been anti-Semitic, as "Zionism" is a keyword even within the context of the TOTALITA1952 reference corpus. The trial records confirm this orientation, as, for instance, 
the list of the accused give information about their nationality - they were sorted as Czech, Slovak, or "Jewish origin"5 (Proces, 1953, pp. 44-45). Moreover, in their staged interrogations, they linked their alleged anti-Communist business with their Jewishness - the accused were connected with such activities as espionage and conspiracy, which had been typical features forming the image of Jewish people as enemies in European history (cf. Steiner, 2002; Koštálová, 2012; Šimová, 2014). During the trial, legends about original Jewish surname Salzman of Rudolf Slánský also appeared, but they were not based on the truth (cf. Slánský's birth record)6; the argument was thus not used at court. However, in case of André Simone, the fact that his original name was Otto Katz was several times mentioned, with his characteristics as "international spy, Zionist and Trockyist" (Proces, 1953, p. 14).

On the other hand, dealing with Zionism in the Rudé právo articles was very sophisticated, as it was presented as an extremist concept of the same harmfulness as anti-Semitism (a keyword in Tables $\mathbf{3}$ and 4); this may have contributed to the fact that even though taking place soon after the end of the Second World War, the trial was not reminiscent of the Nazi treatment with Jews. This strategy can be exemplified upon the following excerpts.

"Our party, as a strictly international party, has always fought anti-Semitism. In the same way, it needs to fight and crush Zionism" (RP November 24, 1952, p. 1).

"[...] And it is Zionism that is a racist chauvinism, in the same way, as it is anti-Semitism, in both of which our people sees an expression of the most disgusting barbarism" (RP November 24, 1952, p. 1).

Moreover, all accusations of potential anti-Semitism present in the trial were categorically refuted by Zdeněk Nejedlý, the minister of education, in his radio speech delivered on December 7, 1952.

"We allegedly triggered a wave of anti-Semitism through the trial - rude, brutal, racial anti-Semitism. [...] And talking about it, they [= Western media] made of the accused people without homeland and conscience poor victims of their faith who had not thought about politics and bad acting at all; they just kept their religion, and therefore they died, therefore their lives were taken by the ugly, atheistic Communists. [...] Nobody can wish Jewish people their national independence more than us. However, nothing can confuse us in our behaviour towards Zionism, if the movement is serving to America" (Nejedlý, 1953, p. 14-16).

Using this hyperbolic rhetoric, the press succeeds in creating the image of monsters that seek to push through their own (e.g., Semitic) interests in a most selfish way.

Collocation

Analysis
The outcomes of the collocation analysis (for the workings, see Part 2) are presented in Tables 5, 6, 7 and 8. For the meaning of the morphological abbreviations, see the appendix of the paper. The total occurrences of the "Slánský" and "Gottwald" lemmata in the trial corpus are 194 and 92, respectively; as to the birthday corpus, "Slánský" appears with the frequency of 176, and "Gottwald" occurs 63 times.

As can be seen, the collocates linked to Gottwald in the first corpus are more numerous and indicate a firm position of the that-time Communist leader, stressing his determination ("leadership"), stately character ("president", "Republic"), affiliation to the Socialist cause ("comrade", "party"), popularity ("beloved"), and steadiness ("around"). In the birthday corpus, he is, moreover, presented as a close friend of Slánský's ("side", "together"); if the accepted MI score value is lowered to 3, "Slánský" even appears as his collocate. In the trial corpus, Gottwald's full title is stressed many times ("the president of the Republic"), so as to show the officiality of his position - in comparison to the conspiracy-based, self-proclaimed management of Slánský, who is referred to as "head" of "companions", which is very vague and implies lack of organization.

\footnotetext{
${ }^{5}$ In his memory book Doznání[The Confession], Artur London states that the accused were originally classified as people of "Jewish nationality"; this was later changed to "Jewish origin" (London, 1969, p. 198).

6 Jiř Čutka, who interviewed Josefa Slánská, Rudolf Slánský’s wife, in 1968, introduced his text as follows: "A family without a father - how many in the same situation there are in Prague, in the Republic! However, this father's name was Slánský, and the family bears his name. And last year, somebody carved the name Salzmann into the door" (Slánská, 2018, p. 226).
} 
Table 5 Collocation analysis of the "Slánský" lemma - the trial corpus

\begin{tabular}{|c|c|c|c|c|c|}
\hline Position & Collocate & Translation & MI score & $\mathrm{Fq}$ (coll) & $\mathrm{Fq}$ (corpus) \\
\hline L & Rudolfem & Rudolf [instr] & 7.06 & 14 & 14 \\
\hline $\mathrm{L}$ & $v$ čele & head [loc] & 6.87 & 27 & 31 \\
\hline L & Rudolf & Rudolf & 6.78 & 9 & 11 \\
\hline $\mathrm{R}$ & společníků & companions [gen] & 6.58 & 5 & 7 \\
\hline $\mathrm{L}$ & Rudolfa & Rudolf [gen] & 6.58 & 5 & 7 \\
\hline L & centra & centre $[$ gen] & 6.2 & 29 & 53 \\
\hline L & hlava & head & 6.06 & 5 & 10 \\
\hline L & protistátního & anti-state [gen] & 5.98 & 16 & 34 \\
\hline L & bandy & gang [gen] & 5.94 & 11 & 24 \\
\hline $\mathrm{R}$ & sionistické & $\begin{array}{l}\text { Zionist [neu, nom; neu, acc; fem, gen; fem, } \\
\text { dat; fem, nom, pl; fem, acc, pl] }\end{array}$ & 5.93 & 5 & 11 \\
\hline $\mathrm{L}$ & spikleneckého & conspirational [masc, gen] & 5.91 & 22 & 49 \\
\hline $\mathrm{R}$ & banda & gang & 5.84 & 18 & 42 \\
\hline L & zrádce & traitor [nom; gen; acc; nom, pl; acc, pl] & 5.69 & 10 & 26 \\
\hline L & spiklenecké & $\begin{array}{l}\text { conspirational [neu, nom; neu, acc; fem, } \\
\text { gen; fem, dat; fem, nom, pl; fem, acc, pl] }\end{array}$ & 5.48 & 5 & 15 \\
\hline
\end{tabular}

Table 6 Collocation analysis of the "Gottwald" lemma - the trial corpus

\begin{tabular}{|c|c|c|c|c|c|}
\hline Position & Collocate & Translation & MI score & $\mathrm{Fq}$ (coll) & Fq (corpus) \\
\hline L & soudruhem & comrade [instr] & 8.15 & 8 & 8 \\
\hline $\mathrm{L}$ & klementa & Klement [gen; acc] & 8.15 & 17 & 17 \\
\hline$L$ & soudruha & comrade [gen; acc] & 7.91 & 43 & 51 \\
\hline L & presidenta & president [gen; acc] & 7.57 & 10 & 15 \\
\hline L & soudruh & comrade [nom] & 7.57 & 34 & 51 \\
\hline$L$ & vedením & leadership [instr] & 7.48 & 5 & 8 \\
\hline L & milovaného & beloved [masc, gen] & 7.42 & 6 & 10 \\
\hline$L$ & kolem & around & 6.79 & 7 & 18 \\
\hline L & slova & words [nom; acc] & 6.39 & 5 & 17 \\
\hline $\mathrm{R}$ & stranu & party $[\mathrm{acc}]$ & 6.15 & 6 & 24 \\
\hline$L$ & republiky & Republic [gen] & 5.87 & 8 & 39 \\
\hline$L$ & strana & party [nom] & 5.74 & 6 & 32 \\
\hline$L$ & strany & party [gen] & 5.71 & 14 & 76 \\
\hline L & život & life [nom] & 5.43 & 5 & 33 \\
\hline $\mathrm{L}$ & banda & gang [nom] & 5.08 & 5 & 42 \\
\hline
\end{tabular}


Table 7 Collocation analysis of the "Gottwald" lemma - the the birthday corpus

\begin{tabular}{|c|c|c|c|c|c|}
\hline Position & Collocate & Translation & MI score & $\mathrm{Fq}$ (coll) & Fq (corpus) \\
\hline L & Rudolfa & Rudolf [gen; acc] & 5.80 & 19 & 18 \\
\hline L & Rudolf & Rudolf [nom] & 5.72 & 18 & 18 \\
\hline L & soudruh & comrade [nom] & 5.52 & 97 & 111 \\
\hline$L$ & soudruha & comrade [gen; acc] & 5.30 & 66 & 88 \\
\hline L & tajemníka & secretary [gen; acc] & 5.13 & 6 & 9 \\
\hline L & statí & studies [gen] & 5.04 & 5 & 8 \\
\hline
\end{tabular}

Table 8 Collocation analysis of the "Gottwald" lemma - the birthday corpus

\begin{tabular}{|c|c|c|c|c|c|}
\hline Position & Collocate & Translation & MI score & $\mathrm{Fq}$ (coll) & Fq (corpus) \\
\hline L & Klementa & Klement [gen; acc] & 7.22 & 14 & 14 \\
\hline $\mathrm{L}$ & boku & side [gen; dat; loc] & 7.11 & 13 & 14 \\
\hline $\mathrm{L}$ & vedle & next [adv; prep] & 7.02 & 7 & 8 \\
\hline L & presidenta & president [gen; acc] & 6.99 & 6 & 7 \\
\hline L & soudruhem & comrade [instr] & 6.68 & 11 & 16 \\
\hline L & spolu & together & 6.22 & 6 & 12 \\
\hline L & soudruha & comrade [gen; acc] & 5.89 & 35 & 88 \\
\hline L & po & by & 5.19 & 13 & 53 \\
\hline
\end{tabular}

Furthermore, the trial-corpus collocates around "Slánský" are very expressive ("traitor", "gang") and form almost an epithet-like apposition "Slánský, head of the anti-state conspirational centre". This notion has multiple associations - first, as aforementioned, it indicates lack of structure; second, it focuses on the fact that the main protagonist of the trial is the brains of all the operation ("centre"); and third, it underlines its secretive and illegal character ("conspirational"). On the other hand, in the birthday corpus, Slánský is referred to as "comrade" and "secretary", and the importance of his literary works is emphasised as well (collocate "studies"). The use of collocate "comrade" in the genitive and accusative cases may manifest his link to Klement Gottwald, which is thus mutual. Compare the listed examples.

"[...] comrade Slánský presented himself, by comrade Gottwald's side, as one of the leading representatives of the Bolshevik direction" (RP July 31, 1951, p. 3).

"In the studies and speeches by comrade Slánský, we find a lot of valuable material and practical advice [...]" (RP July 31, 1951, p. 4).

"For 25 years, comrade Slánský has been a close helper of comrade Klement Gottwald" (RP July 31, 1951, p. 4).

From now on, we will focus our attention on a detailed analysis of the trial corpus. With a certain licence, it is possible to see the rhetoric link between the Slánský case and Cicero's speeches against the conspiracy of Catilina - the formal resemblance of the two situations provided the authors of the articles with very powerful stylistic tools (rhetoric questions, adjectival characterizations, Latin-like periods, pathos). See the following examples.

"What was the goal of the conspirational gang of Slánský and his companions?" (RP November 24, 1952, p. 1). 
"Slánský's gang was aware of the fact that comrade Gottwald, beloved by our people, is firmly holding the steering wheel of our people's democratic republic and that until comrade Gottwald leads our people, the plans of the conspirators will fall flat" (RP November 21, 1952, p. 1).

"Rudolf Slánský, head of the anti-state conspirational centre, was interrogated as the first one" (RP November 21, 1952, p. 1).

"One of the criminals, who were installed in leading positions by Slánský and his gang, was Smrkovský, a Gestapo agent" (RP November 22, 1952, p. 1).

The same as in case of keywords, the adjective "Zionist" makes a prominent appearance as a collocate to Slánský, emphasising the aforementioned importance of Jewishness in the trial. Zionism is linked to American espionage, cosmopolitanism, even Fascism, as is exemplified upon the following examples.

"[...] crook Slánský focused on Zionist organisations and Zionists [...]" (RP November 24, 1952, p. 1).

"After February 1948, Slánskýs Trockyist-Zionist underground takes over the role of the most important enemy agency [...]" (RP November 25, 1952, p. 1).

"Frank (a second Frank, after K. H. Frank [the Nazi politician, the Reich minister for the Protectorate Bohemia and Moravia in the period of 1942-1945], that is sitting on this bench) with Frejka are posting, according to Slánský's guidelines, Zionist tricksters with no homeland [...] into our companies" (RP November 28, 1952, p. 2).

"Zionist organizations, with which Slánský cooperated, were nothing but Fascist storm troops" (RP November 24, 1952, p. 1).

Furthermore, it is also important that in the trial corpus, the first name of Gottwald ("Klement") is not a collocate, whilst "Slánský" is typically linked with "Rudolf" - this may imply that Gottwald is basically an institution ("comrade Gottwald"), not a person in itself; it is an embodiment of the ideology he proclaims. On the other hand, Slánský has been deprived of all his political functions - he is thus a has-been, and the only thing that cannot be taken off him is his name. This interpretation is further supported by the fact that Gottwald is quoted as a high authority (collocate "words"), whereas Slánský is self-contained - his deeds are not widespread, they are merely a dangerous deviation from the main course of the state. Compare the following examples.

"And comrade Gottwald showed our people how to build Socialism" (RP November 27, 1952, p. 1).

"Comrade Gottwald showed that 'it was an extensive conspiracy within the party aiming at taking control of the party, changing its policy [...]'” (RP November 21, 1952, p. 1).

Finally, yet importantly, a specific group is formed by the Gottwald collocates "life" and "gang" - they refer to the alleged attempt of Slánský's group to assassinate Klement Gottwald with the help of doctor Vladimír Haškovec, who is characterized as a "freemason". The collocate "gang", which is the only one shared by the two protagonists, signifies a point of culmination, through which the actions by the anti-state centre, kept secret so far, were supposed to burst into the president's life.

"This perverted doctor was ready to fulfil Slánskýs commands - following his instructions, he sought to end comrade Gottwald's life" (RP November 22, 1952, p. 5).

"And this cosmopolitan and Zionist [...] strives to destroy the most precious, the rarest thing that had ever been produced by the Czech land, the life of comrade Klement Gottwald" (RP November 24, 1952, p. 7).

To conclude, the polar differentiation of the two main figures of the trial seems to be an important feature of the trial corpus. Given the situation in the birthday corpus, it was vital to keep the former co-workers apart, to isolate Slánský from the party policy, and stress out the personal character of his supposed treachery. This is connected to the seemingly paradoxical fact that in both corpora, the lemma "Gottwald", even though appearing much 
less frequently than "Slánský", manifests a slightly denser collocation network ( 8 collocates versus 6 ones in the birthday corpus, 14 collocates versus 15 ones in the trial one). The reasons for this fact are different in either corpus: in the former, Gottwald's role is predetermined and limited, as he is presented as a companion of Slánský's; in the latter, it is needed to put him in the first place and underline his statesmanship, likeability, and merits - this calling, once again, for a high number of fixed collocates.

\section{Conclusions}

The analysis, which was focused on the treatment of personal names in the opinion journalism texts referring to Slánský's trial, showed the following features of their usage.

1 Even though the trial took part in the anti-Semitic atmosphere, this fact was presented in a rather sophisticated way. The trial took place only seven years after the end of the Second World War, and its organizers did not want to wake up recollections of the Nazi treatment with Jews; moreover, the accused persons' collaboration with Nazis was frequently emphasized. The strategy used during the trial was based on fully understandable allusions. The persons were accused of Zionism, and their Jewish origin was mentioned; in case of André Simone, his original name Otto Katz was recollected as well.

2 In the perspective of keyword analysis, the texts were not aimed at personal names in general. It is possible to explain the fact with the Communist regime's goal to sentence the criminals and not to come back to the case details in later issues of Rudé právo; there, only several names were recollected, but in general, the trial was regarded as a closed case.

3 Despite the previous conclusion, the polar differentiation of the two main figures, Klement Gottwald and Rudolf Slánský, seems to be an important feature of the that-time trial presentation, which was proved by the collocation analysis. This built-up antagonism is even more visible when contrasted to the situation during the celebration of Slánský's birthday (the end of July 1951). The fact that Gottwald and Slánský were presented as closely linked at that time made the necessity to separate them even more urgent. During the trial, Klement Gottwald was thus showed as the authority, in the contrast to Rudolf Slánský, who was the head of the anti-state centre and whose aim was to assassinate the embodiment of the Republic.

4 Stylistically, frequent use of extended epithets in case of the aforementioned figures ("beloved comrade Gottwald" vs. "Rudolf Slánský, head of the anti-state conspirational centre") creates imprints in the readers' memories and helps to stabilize the protagonists' prefabricated characteristics.

Furthermore, the research can be developed in multiple ways - first, it possible to quantitatively analyze various other style features of the studies corpora; second, more texts on Slánský's trial may be included in the investigation; and third, accounts of various political trials from the 1950s can be compared to each other on the stylometric grounds.

\section{References}

1 Brabec, V. (1969). Vztah KSČ a veřejnosti k politickým procesům na počátku padesátých let [Attitude of the Communist Party of Czechoslovakia and the Public towards the Political Trials at the Beginning of the 1950s]. In: Revue dějin socialismu, 9(3), 363-385.

2 Brezina, V., McEnery, T., \& Wattam, S. (2015). Collocations in context: A new perspective on collocation networks. International Journal of Corpus Linguistics, 20(2), 139-173. https://doi.org/10.1075/ ijcl.20.2.01bre

3 Coates, R. (2006). Properhood. Language, 82(2), 356-382. https://doi.org/10.1353/ lan.2006.0084
4 Cvrček, V. (2019). Asociační (kolokační) míry [Association (Collocation) Measures]. Available at: <https://wiki.korpus.cz/doku. php/pojmy:asociacni_miry>.

5 Davidová Glogarová, J., \& David, J. (2020). The Radio Speeches of Czech Exile Politicians in the Period of 19391945 in the Perspective of Thematization of Proper Names. Historický časopis, 68(5), 841-860. https://doi.org/10.31577/ histcaso.2020.68.5.4

6 Davidová Glogarová, J., \& Kubát, M. (2020). Srovnávací frekvenční analýza exilových projevů Klementa Gottwalda a Edvarda Beneše z let 1939-1945 [A Comparative Frequency Analysis of the Exile Speeches 
of Klement Gottwald and Edvard Beneš, 1939-1945]. Slovo a slovesnost, 81(1), 65-77.

7 Kaplan, K. (1992). Zpráva o zavraždění generálního tajemníka [Report on the Murder of the General Secretary]. Praha: Mladá fronta.

8 Koštálová, P. (2012). Stereotypní obrazy a etnické mýty. Kulturní identita Arménie [Stereotypical Images and Ethnic Myths. The Cultural Identity of Armenia]. Praha: Sociologické nakladatelství (SLON).

9 Kourová, P. (2013). Propagandistické kampaně v Československu v letech 1948-1953 [Propaganda Campaigns in Czechoslovakia 1948-1953]. PhD thesis. Praha: Univerzita Karlova.

10 KWords [online]. ÚČNK, 2015. Available at: $<$ https://kwords.korpus.cz>.

11 Lukes, I. (2008). Rudolf Slansky: His Trials and Trial. Washington: Woodrow Wilson International Center for Scholars.

12 McEnery, T., Xiao, R., and Tono, Y., 2006. Corpus-Based Studies: An advanced resource handbook. Oxon / New York: Routledge.

13 Místecký, M. (2019). Vers la définition pragmatique de la collocation: méthodes statistiques exemplifiées sur les articles journalistiques traitant la crise migratoire [Towards a Pragmatic Definition of Collocation: Statistical Methods Exemplified upon Newspaper Articles Focused on Migration Crisis]. Studia Romanistica, 19(1), 73-83.

14 Nečasová, D. (2020). Obrazy nepřítele v Československu 1948-1956 [Images of Enemy in Czechoslovakia 1948-1956]. Praha: Nakladatelství Lidové noviny.

15 Nyström, S. (2016). Names and Meaning. In: Names and Naming, (ed.) Hough, C. Oxford: Oxford University Press, pp. 39-66. https://doi.org/10.1093/ oxfordhb/9780199656431.013.26

16 Palivodová, E. (2012). Obraz nepř́tele v Československu 1948-1956 [Image of Enemy in Czechoslovakia 1948-1956]. In: Kontexty propagandy, (eds.) Kouba,
M., Magincová, D., \& Říha, I. Pardubice: Univerzita Pardubice, pp. 181-188.

17 Pelikán, J. (ed.). (1975). The Czechoslovak Political Trials, 1950-1954. The Suppressed Report of the Dubcek Government's Commission of Inquiry, 1968. Stanford: Stanford University Press.

18 Pernes, J., \& Foitzik, J. (2005). Politické procesy v Československu po roce 1945 a «Prípad Slánský» [Political Trials in Czechoslovakia after 1945 and the Case of Slánský]. Brno: Prius.

19 Schmiedtová, J. (2014). Srovnání kolokací totalitníhojazykavbývalémČeskoslovensku s jazykem současným [A Comparison of Collocations in the Totalitarian Language of the Former Czechoslovakia and Those in Contemporary Czech]. Časopis pro moderní filologii, 96(2), 165-179.

20 Steiner, P. (2002). Poetika politického procesu. Dělný lid kontra Rudolf Slánský a spoluspiklenci [Poetics of the Political Trial. Working People vs. Rudolf Slánský and his Fellow Conspirators]. In: Lustrování literatury. Česká fikce $\vee$ politickém kontextu. Praha: Nakladatelství Lidové noviny, pp. 175-224.

21 Ströbinger, R. (1991). Vražda generálního tajemníka: Poslední Stalinův exemplární proces. Soud s Rudolfem Slánským [Murder of the General Secretary: Stalin's Last Exemplary Trial. The Judicial Proceeding with Rudolf Slánský]. Brno: Petrov.

22 Svobodová, J. (2016). Manipulace a argumentace $v$ politickém a mediální diskurzu [Manipulation and Argumentation in the Political and Media Discourse]. Olomouc: Univerzita Palackého.

23 Šimová, K. (2014). Odrodilci, zrádci, vrazi v bílých pláštích: obraz «Žida» jako «neprítele» $\vee$ propagandě pozdního stalinismu [Renegades, Traitors, Murderers in White Coats: The Image of the 'Jew' as 'Enemy' in Late Stalinist Propaganda]. Soudobé dějiny, 21(1-2), 11-43. https://doi. org/10.51134/sod.2014.001

24 Šrámek, R. (1999). Úvod do obecné onomastiky [Introduction into General Onomastics]. Brno: Masarykova univerzita. 
Corpora

Trial

Sources
1 Cvrček, V., Čermák, F., \& Schmiedtová, E. (2010). Slovník komunistické totality [Dictionary of Communist Totality]. Praha: Nakladatelství Lidové noviny.

2 Rudé právo: Rudé právo newspaper. Available at: http://archiv.ucl.cas.cz/index. php?path=RudePravo.

3 Slánský_corpus_1_1952: Rudé právo -

1 Bacílek, K. (1953). Poučenie z procesu s vedením protištátneho špionážneho a sprisahaneckého centra na čele s Rudolfom Slánským [The Lesson Drawn from the Trial of the Leadership of the Anti-State Spy and Conspirational Centre Headed by Rudolf Slánský]. Bratislava: Slovenské vydavatel'stvo politickej literatúry.

2 Bünpere.(1953). RudolfSlánskyés államellenes összeesküvö-központ vezetöinek bünpere [Trial of the Leadership of the Anti-State Conspirational Centre Headed by Rudolf Slánský]. Prága: Orbis.

3 Löbl, E. (1968). Svedectvo o procese s vedením protištátneho sprisahaneckého centra na čele s Rudolfom Slánskym [Testimony of the Trial of the Leadership of the Anti-State Conspirational Centre Headed by Rudolf Slánský]. Bratislava: Vydavatel'stvo politickej literatúry.

4 London, A. (1969). Doznání [The Confession]. Praha: Československý spisovatel.

5 Margoliová-Kovályová, H. (2003). Na vlastní kůži [Having First-hand Experience]. Praha: Academia.

6 Nejedlý, Z. (1953). K procesu s protistátním spikleneckým centrem. 4 projevy $v$ Čs. rozhlase [On the Trial of the Leadership of the Anti-State Conspirational Centre. Four Speeches in the Czechoslovak Radio]. Praha: Československý spisovatel.

7 Poučení. (1988). Poučení z krizového vývoje ve straně a společnosti po XIII. sjezdu KSČ. Rezoluce k aktuálním otázkám jednoty strany [The Lesson Drawn from the Crisis in the Party and Society after the 13th Congress of the Communist Party of Czechoslovakia. Resolution to the Current Problems of the Party Unity]. Praha: Svoboda. everyday coverages of the trial, texts, and letters. Available at: https://github.com/ MichalMistecky/David_Davidova_Mistecky_ Slansky.

4 Slánský_corpus_2_1951: Slánský's 50th birthday - letters, essays. Available at https://github.com/MichalMistecky/David_ Davidova_Mistecky_Slansky.

8 Proces. (1953a). Proces s vedením protistátního spikleneckého centra $v$ čele $s$ Rudolfem Slánským [Trial of the Leadership of the AntiState Conspirational Centre Headed by Rudolf Slánský]. Praha: Ministerstvo spravedlnosti.

9 Proces.(1953b). Processvedením protištátneho sprisahaneckého centra na čele s Rudolfom Slánským [Trial of the Leadership of the AntiState Conspirational Centre Headed by Rudolf Slánský]. Praha: Ministerstvo spravodlivosti.

10 Procès. (1953). Procès des dirigeants du centre de conspiration contre l'Etat dirigé par Rudolf Slánský [Trial of the Leadership of the AntiState Conspirational Centre Headed by Rudolf Slánský]. Prague: Orbis.

11 Proceso. (1953). Proceso contra el núcleo dirigente del centro conspirativo antiestatal encabézado por Rudolf Slánský [Trial of the Leadership of the Anti-State Conspirational Centre Headed by Rudolf Slánský]. Praga: Ministerio de justicia.

12 Process. (1953). Process rukovoditelej antigosudarstvennogo zagovorščickogo centra vo glave s Rudol'fom Slanskim [Trial of the Leadership of the Anti-State Conspirational Centre Headed by Rudolf Slánský]. Praga: Orbis.

13 Prozess. (1953). Prozess gegen die Leitung des staatsfeindlichen Verschwörerzentrums mit Rudolf Slánský an der Spitze [Trial of the Leadership of the Anti-State Conspirational Centre Headed by Rudolf Slánský]. Prag: Orbis.

14 Skála, I. (1952). Tři lavice [Three Benches]. In: Rudé právo, no. 318, November 28, p. 2.

15 Slánská, J. (2018). Zpráva o mém muži [Report on My Husband]. Praha: JOTA - ÚSTR.

16 Slánský’s birth record: National Archive in Prague, Jewish Registers, Register of Births, 
the City of Spálené Poříčí (the district of Plzeňjih), 1868-1922, 1924-1933 [online]. [accessed March 13, 2020]. Available from: <https:// bit.ly/3a6acza> Available at <http://www. badatelna.eu/fond/1073/reprodukce/?zaznaml $d=2526 \&$ reprold $=160362>$.
17 Trial (1953). Trial of the Leadership of the AntiState Conspiracy Centre Headed by Rudolf Slánský. Prague: Orbis.

\section{Acknowledgement}

The research, mostly concerning the topic of people's nationality presentation and perception through their personal names, was supported by the grant project SGS01/FF/2020-2021 Reflexe jazykové a jazykovědné problematiky v nelingvistických textech [Reflection of Language and Linguistic Issues in Non-Linguistic Texts], provided by the Faculty of Arts, the University of Ostrava.

Appendix. List of the abbreviations used in the study

\begin{tabular}{|c|c|}
\hline Abbreviation & Meaning \\
\hline acc & Accusative Case \\
\hline adj & Adjective \\
\hline$a d v$ & Adverb \\
\hline dat & Dative Case \\
\hline fem & Feminine Gender \\
\hline gen & Genitive Case \\
\hline imp & Imperative Mood \\
\hline instr & Instrumental Case \\
\hline loc & Locative Case \\
\hline neu & Neuter Gender \\
\hline nom & Nominative Case \\
\hline past part & Past Participle \\
\hline $\mathrm{pl}$ & Plural Number \\
\hline prep & Preposition \\
\hline sg & Singular Number \\
\hline
\end{tabular}

\section{Santrauka}

Michal Místecký, Jana Davidová Glogarová, Jaroslav David. Dviejų vyrų šou: stilometrinė asmenvardžių analizė laikraščio straipsniuose nušvietusiuose Rudolfo Slanskio parodomojo teismo procesą.

Straipsnio tikslas - išanalizuoti asmenvardžius (antroponimus) laikraščio straipsniuose, nušvietusiuose parodomaji Rudolfo Slanskio teismą. Šio proceso metu buvo teisiami daugiausia žydų kilmès Čekoslovakijos komunistų partijos lyderiai, kurie buvo paskelbti politiniais priešais. Teismo procesas vyko antisemitinèje atmosferoje. Šiame tyrime analizuojami straipsniai, kurie pasirodè pagrindiniame Čekoslovakijos komunistų laikraštyje „Rudé právo“ 1952 metụ lapkričio 21-28 dienomis. Tikriniai daiktavardžiai, daugiausia asmenvardžiai, nagrinèti 
iš keliụ perspektyvų. Kiekybinèje analizejje pagrindinis dėmesys skiriamas raktiniams žodžiams ir tipinėms kolokacijoms su vardais. Kokybine analize siekiama ištirti priešo ar išdaviko ịvaizdị ir jo raišką per asmenvardžių tematizavimą. I straipsnio tyrimo lauką taip pat patenka ir kalbinis kaltinamujjų žydų kilmès pateikimas. Kolokacijos iš straipsnių apie teismo procesą gretinamos su kolokacijomis rastomis „Rudé právo“ straipsniuose, išspausdintuose Rudolfo Slanskio 50-ojo gimtadienio proga (1951 m. liepos 31 d.).

About the Authors

\section{MICHAL MÍSTECKÝ}

PhD, Assistant Professor at the Department of Czech Language, Faculty of Arts, University of Ostrava

Research interests

Corpus linguistics, stylometry, onomastics, didactics.

\section{Address}

Reální 5, 70103 Ostrava, Czech Republic

ORCID iD

0000-0002-9183-4435

\section{JANA DAVIDOVÁ GLOGAROVÁ}

$\mathrm{PhD}$, Assistant Professor at the Centre for Economic and Social History, Faculty of Arts, University of Ostrava

\section{Research interests}

Text analysis, modern Czechoslovak history, Czech literature, ideology.

\section{Address}

Reální 5, 70103 Ostrava, Czech Republic

ORCID iD 0000-0002-3946-1379

\section{JAROSLAV DAVID}

$\mathrm{PhD}$, Associate Professor at the Department of Czech Language, Faculty of Arts, University of Ostrava

Research interests Onomastics, text analysis, historical grammar, corpus linguistics.

\section{Address}

Reální 5, 70103 Ostrava,

Czech Republic

ORCID iD

0000-0003-2443-5351 